IZA DP No. 6006

Firing Regulations and Firm Size in the Developing World:

Evidence from Differential Enforcement

Rita K. Almeida

Z. Bilgen Susanlı

October 2011 


\title{
Firing Regulations and Firm Size in the Developing World: Evidence from Differential Enforcement
}

\author{
Rita K. Almeida \\ World Bank \\ and IZA
}

\section{Z. Bilgen Susanlı \\ Ișk University}

\section{Discussion Paper No. 6006 \\ October 2011}

\author{
IZA \\ P.O. Box 7240 \\ 53072 Bonn \\ Germany \\ Phone: +49-228-3894-0 \\ Fax: +49-228-3894-180 \\ E-mail: iza@iza.org
}

\begin{abstract}
Any opinions expressed here are those of the author(s) and not those of IZA. Research published in this series may include views on policy, but the institute itself takes no institutional policy positions.

The Institute for the Study of Labor (IZA) in Bonn is a local and virtual international research center and a place of communication between science, politics and business. IZA is an independent nonprofit organization supported by Deutsche Post Foundation. The center is associated with the University of Bonn and offers a stimulating research environment through its international network, workshops and conferences, data service, project support, research visits and doctoral program. IZA engages in (i) original and internationally competitive research in all fields of labor economics, (ii) development of policy concepts, and (iii) dissemination of research results and concepts to the interested public.
\end{abstract}

IZA Discussion Papers often represent preliminary work and are circulated to encourage discussion. Citation of such a paper should account for its provisional character. A revised version may be available directly from the author. 
IZA Discussion Paper No. 6006

October 2011

\section{ABSTRACT \\ Firing Regulations and Firm Size in the Developing World: Evidence from Differential Enforcement}

This paper examines how stringent de facto firing regulations affect firm size throughout the developing world. We exploit a large firm level dataset across 63 countries and within country variation in the enforcement of the labor codes in countries with very different de jure firing regulations. Our findings strongly suggest that firms facing a stricter enforcement of firing regulations are on average smaller. We interpret this finding as supportive of the fact that more stringent de facto firing regulations tend to reduce average employment. We also find robust evidence that this effect is stronger for more labor intensive manufacturing firms, especially those operating in low-technology sectors. Evidence also shows that this negative correlation does not hold in countries with a very weak rule of law.

JEL Classification: J21, J24, K20

Keywords: labor markets, developing countries, firing regulations, enforcement, micro data

Corresponding author:

Rita Almeida

The World Bank

1818 H Street NW

Washington DC, 20433

USA

E-mail: ralmeida@worldbank.org

\footnotetext{
* We are grateful to the editor and two anonymous referees for very helpful and detailed comments on an earlier draft of this paper. We would also like to thank participants at the Third IZA/WB Conference on Employment and Development in Morocco, especially Jim Albrecht, Carmen Pagés, Jan Svejnar and participants at the seminar at Ișık University for helpful comments. This project would not have been possible without the financial support of a World Bank Research Support Grant granted to Rita Almeida.
} 


\section{Introduction}

Substantial research has been devoted to the effect of labor market regulations in several labor outcomes in the developing world (Heckman and Pagés, 2004). However, the effects of specific dimensions of labor regulations have been much less studied. Furthermore, in developing countries there is a big gap between the de facto and the de jure regulation, as enforcement is weak and evasion is large. This paper studies the effect of more stringent de facto firing regulations on average firm size in the developing world. In the presence of adverse economic conditions, strict firing regulations increase the cost of firing and may severely discourage firms from adjusting their workforce. Moreover, strict firing regulations also likely affect the firm's hiring decisions. For example, in good times, as firms anticipate higher firing costs, it is plausible that firms hire fewer workers, to avoid future costs in laying them off. Therefore, at least theoretically, it is unclear the overall effect of higher de facto firing costs on average firm size.

This paper explores a large firm level data set across 63 developing countries. It explores within country variation in the enforcement of firing regulations to see how these affect total firm size in the developing world. Firing regulations refer to advance notice and procedural requirements that are mandatory when workers are fired. In most countries, advance notice procedures impose a pre-notification period. This usually delays the termination of employment with a firm as third parties need to be notified and be in agreement. There is evidence that stricter firing likely affect the employment choices of firms in the developing world (Boeri et al., 2008).

We explore within country variation in the de facto firing regulations faced by firms. In developing countries there is a large gap between the written law and its effective implementation. Labor markets in developing countries are usually characterized by weak 
enforcement of the law and a large informal sector (UNDP Commission Report, 2004). For this reason, the same regulation in countries with very different degrees of enforcement may produce different effects on given firm outcomes. In this paper, we compare total firm size, measured by total permanent employees, for firms facing different degrees of enforcement of firing regulations and located in countries with different degrees of stringency of firing regulations. Exploring variation in enforcement in developing countries is conceptually closer to comparing countries with different degrees of de facto regulations (Almeida and Carneiro, 2009).

Most of the literature studying the effects of labor regulations has not taken into account variation in the enforcement of the law. Some recent exceptions include Boeri and Jimeno (2005); Caballero et al. (2004); Almeida and Carneiro (2007, 2009); Ronconi (2010) and Almeida and Aterido (2011). For example, Almeida and Carneiro (2009) look at how enforcement of labor regulations in Brazil constrains firm size and other firm characteristics. They proxy enforcement of labor regulation faced by each firm with the labor inspections at the city level. They show that stricter enforcement of labor regulations constrains firm size (almost all of this concentrated in unskilled workers) and leads to reduced use of informal labor.

Our paper is closely related to the empirical work exploring within country variation in the exposure of firms to different types of firing regulations. ${ }^{1}$ In several countries (such as Italy or Spain) firms that are smaller than a given threshold are not required to comply with all labor regulations set by the law. This exemption provides a discontinuity in the effects of regulations within countries. Under certain conditions, the comparison between these two groups of firms

\footnotetext{
${ }^{1}$ A related strand of the literature explores within-country time series variation in labor regulations in developing countries (including job protection laws). Besley and Burgess (2004) and Ahsan and Pagés (2009) explore time variation at the state-level in India and find that stricter pro-worker labor regulation has a negative impact on state aggregate employment.
} 
can be informative of the causal effects of the regulations on labor market outcomes. For example, Boeri and Jimeno (2005) and Abidoye, et al. (2009) document that workers of small firms are more likely to be laid-off as they are not subject to stringent employment protection. However, Schivardi and Torrini (2008) report higher separation rates for the workers of the larger firms. This is likely explained by the increased use of temporary contracts. Earlier research tried to quantify the impact of labor regulations in developed countries, by exploring the cross country and time series variation in labor regulations (e.g. Lazear, 1990, Nickel and Layard, 1999). These studies typically relied on the cross country variation in de jure labor market regulation. However, identification based on the cross country time series variation in de jure regulation has well-known shortcomings such as omitted variables, measurement error and the difficulty in determining the direction of causality (Micco and Pagés, 2006; Kugler, 2007).

This paper investigates the link between de facto firing regulations and firm size. We explore a large firm-level dataset across several developing countries and compare firm size for firms facing different degrees of enforcement of firing regulations. We explore the Enterprise Surveys, collected by the World Bank. The data is particularly useful to analyze this topic. It collects detailed information on labor force characteristics, including alternative measures of firm size, as well as proxies for the enforcement of different types of regulations, including labor regulations. We also use the Doing Business dataset collected by the World Bank. In particular, we explore the difficulty of firing index which captures cross country differences in the stringency of firing regulations in the de jure law. ${ }^{2}$ We also use the rigidity of employment index

\footnotetext{
${ }^{2}$ The index is computed so that it is comparable across countries. In particular, they define a profile of workers and of firms to which the regulations refer to. The average worker is on 42 years old, a full time employee and has the most common pay period in the economy. Labor earnings are also equal to the economy's average wage during the
} 
and the number of procedures to start a business. The former is a general measure of the degree of stringency of employment related regulations. It covers the difficulty in hiring, in adjusting work hours as well as the difficulty in firing workers. The number of procedures to start a business captures the number of procedures, including necessary permits and licenses, required for a company to be legally in operation.

Our prior is that firing regulations will be more binding when firms face stricter enforcement of the law. In other words, a stricter enforcement of firing regulations (or a more stringent de facto firing regulations) increases the cost to firms of adjusting labor and potentially will affect both hiring and firings, and ultimately firm size We follow Almeida and Aterido (2011) and measure enforcement of regulations with the number of days of visits done by labor inspections in each firm. We also use information on the total number of inspections, including labor, environment, fire, health, sanitation and tax inspections. ${ }^{3}$

Our empirical approach is close to a "differences-in-differences" model. We are interested in the effect of stricter de facto firing regulations (or the "treatment") on the firms' choice of workforce size. In this case, we could define "treatment" as facing a stricter enforcement and more rigid firing regulations in a country. Firms that face weaker enforcement can be considered as a "control group". We compare firms with similar observable characteristics (e.g. age, ownership type, sector of activity, export status and location) within the same country but differing in the degree of enforcement of labor regulations that they face. In our reduced form model, we account for the unobserved country and sector characteristics that entire period of his employment. This profile is therefore closer to the profile of a permanent employee with the firm.

${ }^{3}$ Almeida and Aterido (2011) explore an empirical approach similar to the one we use here to analyze the link between enforcement of labor market regulations and the investment in on the job training. 
are likely to be correlated with the de facto firing regulations and firm size (e.g. the level of development of each sector in the country), by including country-sector fixed effects. ${ }^{4}$ We also control for several firm-level characteristics correlated with firm size and the strictness of the de facto firing regulation. In addition we control for differences across firms in the degree of enforcement of the labor law that they face.

Our findings show that firms that are subject to stricter de facto firing regulations (for example at the $90^{\text {th }}$ percentile of enforcement of labor market regulations) in a country with rigid firing regulations (e.g. Ecuador, in the $90^{\text {th }}$ percentile of the difficulty of firing index) are 15 percent smaller than firms subject to looser enforcement in a country with less rigid regulations (e.g. Guatemala, in the $10^{\text {th }}$ percentile of the difficulty of firing index). This reduction in firm size tends to be larger for the manufacturing sector and, especially in low technology sectors with higher labor intensity. It is reassuring to see that our results do not hold in countries that are characterized by weak rule of law.

Our findings bear important policy implications. A stricter enforcement of firing regulations in countries, where these laws are stricter, constrains firm size. This will lead to a lower employment rate unless smaller firm size is not compensated by increased entry of firms. To the extent that economic growth is driven by growth of existing firms, rather than by the creation of new firms, the effect of strict de facto firing regulations on firm size matters for economic growth (Rajan and Zingales, 1998). High levels of labor regulations and extensive informality are associated with lower levels of economic growth (Loayza et al., 2006) In general, the adverse effects of different types of regulations on growth varies depend on the quality of the institutional environment. Taken together, the findings of this paper should not be

\footnotetext{
${ }^{4}$ All our results remain when we control for country and sector fixed effects separately.
} 
interpreted as suggesting to eliminate firing regulations altogether. Furthermore, a high quality institutional environment is indispensable for enhancing growth and development. However, in the developing world, with pervasive informality, a more effective policy recommendation is to promote more flexible labor laws coupled with higher compliance levels. This could happen instead of lifting heavily the enforcement of strict firing regulations. ${ }^{5}$

The paper is organized as follows. Section 2 describes the datasets used and presents summary statistics. Section 3 explains the empirical methodology. Section 4.1. reports the main empirical findings. Section 4.2 and 4.3 discuss several robustness checks, especially to address the concerns with the endogeneity of de facto firing regulations and the heterogeneity of the results to alternative groups of firms and countries Section 5 concludes.

\section{Data and Descriptive Statistics}

We explore the Enterprise Surveys, collected by the World Bank, across 63 developing countries. ${ }^{6}$ The surveys were conducted between 2002 and 2005 and the samples were designed to be representative of the population of firms according to their industry and location within each country.

\footnotetext{
${ }^{5}$ Schneider (2005) estimates that the average the size of the shadow economy (as a percentage of the official GDP) in 2002-2003 is 38\% across 96 developing countries. He highlights the role of taxation and social security contributions together with strict labor market regulations as contributing to the informal sector.

${ }^{6}$ The Enterprise Surveys are currently available for a larger set of countries. We restrict the attention to 63 countries due to the lack of information on the main variables of interest. This dataset has been used in many other studies (e.g. Svensson, 2003; Pierre and Scarpetta, 2006; Aterido et al., 2007; Almeida and Carneiro, 2009; Almeida and Aterido, 2011).
} 
The information available in the survey has several advantages for analyzing the effects of firing regulations on firm size. First, it is based on a common questionnaire across a large set of countries, which yields comparable information on several firm-level variables. Among other things, the survey collects detailed information on labor market variables, like firm size and workforce composition and other detailed firm characteristics (e.g. firm ownership structure, age, exports and imports). Second, the survey collects detailed information on the enforcement of different pieces of regulation, including labor market regulations. In particular the survey asks "On average, how many days last year were spent in inspections and mandatory meetings with officials of each of the following agencies?” The survey then lists the tax inspectorate, labor and social security, fire and building safety, sanitation, municipal police and environment. Our main measure of enforcement of labor regulations at the firm level is captured by the number of days of labor inspections. We use alternative firm level variables that capture the quality of the enforcement of general de jure regulations in the country. These include total number of days spent by managers with all inspections (labor and others), the manager's perception on the enforcement of property rights in the country or his/her perceptions about the consistency in the application of the regulations in the country.

We explore the Doing Business country level data collected by the World Bank. This data includes detailed information on several regulatory features of the economies, including regulations of entry, labor and product markets. Of special interest to us is the information related to the regulations on firing compiled in the difficulty of firing index. It includes information on the difficulty of dismissing a redundant worker, either individually or collectively. These costs include the advance notifications, approvals, mandatory relocation or 
retraining, and priority rules for re-employment. ${ }^{7}$ Their effect is to raise the costs of dismissal of existing workers.

To measure the degree of regulations in product markets, we also use the number of procedures required to start a business collected from the Doing Business dataset. Finally, we take country level GDP per capita (in 2000 dollars) from World Development Indicators and three governance indicators taken from Kauffman and Kraay (2003) to capture the level of development of the governments and corruption levels ${ }^{8}$.

Table A1 in the appendix defines the variables and table 1 reports the descriptive statistics the main variables used in the empirical analysis. Our final sample covers 30,351 firms across 63 developing countries. Our main outcome of interest is total firm size, which we

\footnotetext{
${ }^{7}$ The index capturing the difficulty in firing contains several components: (i) whether redundancy is disallowed as a basis for terminating workers; (ii) whether the employer needs to notify a third party o terminate a redundant worker; (iii) whether the employer needs to notify and seek approval from a third party to fire redundant workers; (iv) whether the employer needs approval from a third party to terminate a group of 9 redundant workers; (v) whether the law requires the employer to reconsider reassignment or retraining options before redundancy termination; (vii) whether priority rules apply for redundancies; and (vii) whether priority rules apply for reemployment. Higher values of the index indicate more rigid firing regulations.

${ }^{8}$ The governance indicators vary between -2.5 to 2.5 with higher values corresponding to better governance outcomes. Rule of Law is the extent to which agents have confidence in and abide by the rules of the society, and in particular the quality of contract enforcement, the police, and the courts as well as the likelihood of crime and violence; Control of Corruption is the extent to which public power is exercised for private gain including both petty and grand forms of corruption, as well as "capture' of the state by elites and private interests; Regulatory Quality is the ability of the government to formulate and implement sound policies and regulations that permit and promote private sector development.
} 
measure with the total number of permanent workers in the firm. Appendix A2 describes the geographical composition of the sample. In our sample, $28.6 \%$ of the firms are located in East Asia and Pacific, 28.3\% are in Europe and Central Asia, 17\% are in Latin America and Caribbean, 7.8\% are in Middle East and North Africa, 7.6\% are in South Asia and 10.8\% are in Sub-Saharan Africa. About $77 \%$ of the firms in our sample operate in manufacturing while $17.9 \%$ of operate in services sector. ${ }^{9}$

The average firm in the sample is 17 years old, employs 212 permanent workers and has a 1 out of 3 probability of being located in the country's capital city. Approximately, 32\% of the firms in our sample report having temporary workers, which account for 98 employees. These account for $29 \%$ of the total workforce. $78 \%$ of the firms are domestically owned and $8 \%$ have some public ownership. ${ }^{10} 23 \%$ of the firms in our sample are located in large cities that have population greater than a million. In addition, $31 \%$ of the firms in our sample report exporting some of their output.

As to enforcement of labor regulations, the average firm in our sample spent 5 days last year in inspections and mandatory meetings with officials. This ranges from no inspections to 55 days. The average firm in our sample reports having spent on average 10 days in inspections of all types with officials. In addition, firms report that on average $8 \%$ of their senior management's time is spent in dealing with requirements imposed by government regulations. Moreover, $6 \%$ of the firm managers responded positively about whether they trust the judicial system to enforce

\footnotetext{
${ }^{9}$ Approximately $1.5 \%, 3 \%$ and $0.3 \%$ of the firms in our sample operate in agro industry, construction and other industries, respectively.

${ }^{10}$ Our final sample covers 9 sectors at the two-digit ISIC sector of activity. However, in our analyses we use an alternative sector variable that includes 27 categories defined over the activity of the firms. Our sector variable ranges widely from manufacturing of foods, garments and textiles, machinery to construction and electronics.
} 
their property rights in business disputes and only $5 \%$ of them agree that government officials interpret the regulations consistently.

Figure 1 displays the average of the days of labor inspections by firm size and sector of activity. As expected, enforcement increases with firm size. This positive correlation holds across sectors since larger firms are more visible to the inspectors. Figure 2 shows that there is no strong correlation across the country level the rigidity in the de jure firing regulation index and the strictness of enforcement of labor regulations at the country level.

\section{Empirical Approach}

We examine whether the stringency of de facto firing regulations in developing countries affects firm size. Our prior is that a stricter de facto firing regulations increase the costs to firms of adjusting labor and may potentially affect both hiring and firings. The simple reduced form model we use relates the degree of enforcement of labor regulations faced by each firm with the outcomes of interest. ${ }^{11}$ Let $Y_{j c}$ denote firm size in firm $j$ in country $c$ i.e., logarithm of total employment in the firm:

$$
Y_{j c}=\beta F_{c} * E_{j c}+\chi E_{j c}+\delta Z_{j c}+\eta_{c s}+\varepsilon_{j c}
$$

\footnotetext{
${ }^{11}$ Almeida and Aterido (2011) explore a similar approach and show that our reduced form can be derived from a simple model of multiple potential levels of de facto firing regulations each associated with a potential outcome. The model considers a profit-maximizing firm choosing the optimal size of the workforce and where the de facto regulation is unobserved. Letting the de facto firing regulation be a function of the de jure regulation $(R)$ and of enforcement faced by the firm, $(E)$, which is observed in our data, our reduced form can be derived. It can also be shown that our main coefficient of interest, showing how firm size related with de facto firing regulations, is directly proportional to the coefficient in the interaction term in equation (1).
} 
where $F_{c}$ is a measure of the de jure firing costs in country $c, E_{j c}$ is a measure of the enforcement of the labor laws in firm $j$ in country $c, Z_{j c}$ captures firm level pre-determined characteristics of interest of firm $j$ located in country $c$ and $\eta_{c s}$ are time invariant fixed effects capturing country and sector unobserved characteristics. We measure total firm size with total permanent employees in the firm. We measure $F_{c}$ using the Doing Business difficulty of firing index. $E_{j c}$ is measured by the total days of labor inspections in the firm. In $Z_{j c}$ we include a set of predetermined firm characteristics, including age, location of the firm, ownership characteristics (public or foreign capital) and export status. Our main coefficient of interest is the double difference term, $\beta$.

The intuition behind our model is similar to a differences-in-differences approach. We want to estimate the effect of strict firing regulations (the "treatment") on the outcome variable firm size. Our hypothesis is that firms that are located in countries with strict de jure firing regulations and subject to strict enforcement of labor regulations choose their workforce size systematically differently. Hence, the treatment is determined by the interaction term, being subject to both strict enforcement and strict de jure regulations.

The point estimates for $\beta$ can be used to quantify the percentage point difference in logarithm of firm size for a firm facing the $90^{\text {th }}$ percentile of the enforcement of the labor regulation relative to a firm facing the $10^{\text {th }}$ percentile in the enforcement in a country with rigid firing regulation (e.g. in the $90^{\text {th }}$ percentile of the difficulty of firing index) versus the same differential in a country with looser firing regulations (e.g. in the $10^{\text {th }}$ percentile of the difficulty of firing index). This difference is computed assuming that firms operate in the same sector and have the same set of observable characteristics (as captured by $Z_{j c}$ ). Our empirical approach is based on the underlying assumption that the set of country-sector fixed effects, $\eta_{c s}$, is constant 
across firms, regardless of whether the firms are exposed or not to a strict enforcement of the law (Micco and Pagés, 2006; Almeida and Aterido, 2011, have similar assumptions).

It is worth stressing that our empirical approach does not rely on exploring the variation in enforcement of the firing regulations across countries alone. The latter is likely to be endogenous to the firm outcomes. ${ }^{12}$ Instead, we explore the differential effect of enforcement in countries with different degrees of rigidity in the firing regulations, after controlling for countrysector fixed effects, firm characteristics and the enforcement of labor (and also for the enforcement of other types of regulations). By controlling for country-sector fixed effects we are able to account for unobserved country-sector characteristics that are likely to be correlated with de facto labor regulations and with firm size (e.g. level of development of each sector in the country). ${ }^{13}$ This will allow us to overcome the omitted variables problem at the country and sector level by exploring only within country and sector variation. By controlling for the country and sector fixed effects and the firm characteristics, we also hope to minimize the potential reverse causality problem that plagues most of the cross country work. By controlling for the degree of enforcement of labor regulations, we account for (unobservable) firm characteristics

\footnotetext{
${ }^{12}$ A least squares regression of labor inspections on other firm characteristics shows that there is a systematic correlation across inspections and firm observable characteristics. In particular, firms that are older, fully-foreign owned, located in the capital city and managed by managers with a post-graduate degree tend to be inspected more frequently (results not reported but available upon request).

${ }^{13}$ We refrain from presenting the results only exploring variation in the firing regulations across countries because, in the absence of any time series variation, it would not be possible to account for country time-invariant effects. This raises serious concerns regarding potential country-level omitted variables. Moreover, it is likely that countries with larger firm sizes (and possibly lower employment creation) could demand stricter levels of protection. This would make it hard to determine the direction of causality when exploring only cross country variation in de jure regulation.
} 
that could be simultaneously correlated with the enforcement and with firm size in countries with different degrees of rigidities in the firing regulations.

However, our identification also presents some shortcomings. One concern could be that enforcement of labor regulations captures the effects of other factors or institutions also correlated with firm size and with firing regulations. In this case the point estimates for $\beta$ may be biased. We will test the robustness of our findings to the inclusion of additional country variables correlated with the stringency of the de jure firing regulations, and interact them with the level of enforcement of the labor law. These will include the country's level of economic development (proxied by GDP per capita), indices that represent a country's institutional quality (rule of law, regulatory quality and the government control of corruption) and product market regulations (proxied by number of procedures to start a business in a country). Reassuringly, our main findings are robust to the inclusion of these control variables.

In addition, there could still be a general concern regarding the endogeneity of the interaction term, $F_{c} * E_{j c}$. Ideally, we would like to find an instrument that is simultaneously correlated with enforcement of labor regulation and is reasonably exogenous to the outcomes of interest. One possibility would be to follow Almeida and Carneiro (2007, 2009) and compute a measure of how costly it is to supply enforcement in each city. ${ }^{14}$ Unfortunately, we do not know the cities where each firm is located, nor how the labor enforcement is administered across all the countries. In the absence of an analogous instrument, we propose a robustness check using alternative proxies for the enforcement of labor regulations. First, we compute the average

\footnotetext{
${ }^{14}$ Almeida and Carneiro (2009) test the robustness of their findings by using an instrument to enforcement that captures the average distance between the city where the firm is located and all the cities within the same state where a subdelegacia of the Ministry of Labor is located. Distances are measured in hours of travel by car, the type of transportation used by labor inspectors in Brazil.
} 
number of labor inspections in the same city, sector and size group where the firm operates (excluding the own firm). Second, we compute a variable that is smoother than the distribution of enforcement at the country level, by assuming only the value zero and percentiles 25,50 and 75 of the distribution of enforcement within each country. Both variables are positively and strongly correlated with the firm's own reported labor inspections although they are arguably more exogenous to total firm size.

\section{Main Empirical Findings}

\subsection{The Effects of Enforcing Firing Regulations on Firm Size}

Table 2 reports the main findings of estimating equation (1) with least squares after clustering the standard errors at the country and sector level. ${ }^{15}$ Column (1) of table 2 shows that, after controlling for country-sector fixed effects, firms that are exposed to a stricter de facto firing regulations are smaller. ${ }^{16}$ With this coefficient we can quantify the implied 90-10 differential in the log of firm size. The results are reported at the bottom of table 2 . The implied coefficient in column (1) is -26 percentage points. This differential is interpreted as follows: a firm facing the $90^{\text {th }}$ percentile of the enforcement of firing regulations relative to a firm that is facing the $10^{\text {th }}$ percentile is 26 percentage points smaller in a country with rigid firing regulations (e.g. in Ecuador) than in a country with looser regulations (e.g. in Guatemala). This is a large effect since the average log firm size in our sample is 3.8 .

\footnotetext{
${ }^{15}$ We consider a total of 844 categories for country-sector cells.

${ }^{16}$ It is reassuring to see that all the results in table 2 go through if we were to control separately for country and sector fixed effects. The magnitudes of the effect vary between -0.00086 in column (1) to -0.00058 in column (9) (Results are not reported but available upon request).
} 
Columns (2) through (9) of table 2 test the robustness of this finding to alternative robustness checks. In column (2) we add the set of firm level pre-determined controls. Because we are concerned that labor inspections are used for rent extraction motives, in column (3) we control for the total number of inspections faced by the firm and interact total number of inspections with de jure firing regulations. If firms where it is easier to extract rents will have more inspections, this will likely happen for all inspections and controlling for the total inspections, would mitigate this problem. Controlling for total inspections will likely to minimize this concern as long as the probability of having an inspection in order to extract rents is not higher for the labor inspections than for other inspections.

In column (4) we check for the possibility that the stringency of firing regulations is simply capturing the degree of development in the country. This is likely to be the case since it is well-documented in Botero et al. (2003) and Heckman and Pagés (2004) that there is a negative correlation between the strictness of de jure labor regulations and income levels. ${ }^{17}$ To address this we control for the interaction between enforcement of labor regulations at the firm level and the logarithm of GDP per capita in each country. Our coefficient of interest hardly changes.

In columns (5) through (7) of table 2, we also test whether firing regulations are not capturing the effect of other country level institutions, omitted from the analysis but that could be likely to be correlated with these regulations. In particular, we consider differences across countries in the quality of several dimensions of governance and institutional quality. In particular, we consider country's rule of law, regulatory quality and government control of

\footnotetext{
${ }^{17}$ Reassuringly, in our sample, a simple cross country regression of the difficulty of firing index on per capita GDP, shows a significant and negative coefficient. This correlation is robust after to controlling for rigidity of employment and the country average days of labor inspections.
} 
corruption. In column (8) we investigate whether our results could be capturing the impact of differences in entry regulations in the product market other than the effect of firing regulations. ${ }^{18}$ To account for this we control for the interaction between enforcement of labor regulations at the firm level and the number of procedures to start a business, which is a measure of how costly it is to establish a business in a given country. Finally, we investigate whether our findings could be capturing any effects of stringency of hiring regulations and the flexibility in hours. Column (9) controls for the rigidity of employment index, which is an average of the firing index we use and the difficulty of hiring and the rigidities in work hours. Reassuringly, our main results remain the same across all columns. In addition, the positive and significant coefficients of the interaction terms in columns (5) to (7) emphasize the positive impact of better quality institutions on firm size. Interestingly, the coefficient in column (9) is also positive and statistically strong. This implies that, firms facing stricter de facto hiring relations are associated with larger firm sizes. Hiring regulations in the doing business index relates to the extent to which fixed-term contracts are prohibited for permanent tasks and their maximum duration. This positive correlation likely captures the fact that countries that are more developed and have better institutions, have larger firms, but also a stricter de jure hiring regulations and better enforcement of regulations.

\subsection{Additional Robustness Checks}

One concern with the findings reported in our baseline specification, in column (4) of table 2, relates to the fact that firms in developing countries may differ in their propensity to bribe. This, in turn, may be correlated with the enforcement of labor regulations and ultimately

\footnotetext{
${ }^{18}$ Kugler and Pica (2006) document that the impact of firing costs differ depending on the strictness of product market regulations.
} 
with firm size. Moreover, this correlation may be different in countries with different degrees of stringency of firing regulations. Although the inclusion of total inspections in our reduced form already attempts to mitigate this concern, table 3 presents additional robustness checks. In column (1) we investigate whether our results are driven by firms having stricter enforcement eventually differing also in the management's time spent dealing with government officials. In columns (2) and (3) we also check whether the enforcement could be capturing differences across firms in the manager's perception on the enforcement of property rights in the country or his/her perceptions about the consistency in the application of the regulations in the country. Both variables may be correlated with the firms' choice on total size of the workforce as well as with the stringency of enforcement. ${ }^{19}$

Although our main results remain qualitatively the same, we get useful insights from these checks. Results also suggest that firms that report spending more time with officials are smaller in size. We also find evidence that greater perceptions are about the consistency of regulations and enforcement of property rights, the larger the firms are, which confirms the conduciveness of a favorable business environment.

Another concern relates with the possible endogeneity of the de facto firing regulations to firm size. In particular, the number of labor inspections faced by each firm is likely not random to the firm. Even though we do not explore the variation in enforcement alone, rather the interaction of labor inspections and the firing regulations at the country level, one could still be

\footnotetext{
${ }^{19}$ In addition, we use two additional variables. First, we use the "share of sales the firm spends on gifts or making informal payments to public officials to get things done”. Second, we use a binary variable that takes on the value 1 if gifts or informal payments were expected from the firm by labor or other inspectors. Our main results remain the same using these variables. Results are not reported but available upon request.
} 
concerned that this relation is systematically different in countries with different degrees of rigidity of firing regulations. ${ }^{20}$ Columns (4) and (5) of table 3 propose two alternative measures of the enforcement of labor regulations. First, we proxy the enforcement faced by each firm with the mean labor inspections in for firms in the same size-city-sector group where the firm is located (after excluding the own firm). ${ }^{21}$ Second, we proxy enforcement of labor regulations with a smoother variable assuming only a low, medium-low, medium-high or high enforcement level within each country (given by percentiles 25,50 and 75 of the distribution of labor inspections). Reassuringly, our main results remain negative and statistically strong. In both specifications, however, the magnitude of the implied differential becomes larger than in the baseline results in column (4) of table 2. This suggests that our results are a lower bound to the true effects. Most likely enforcement of labor regulations is stricter for countries and regions with better institutions and where firms are larger.

So far, we have measured firm size using the total number of permanent employees in the sample. Table A3 in the appendix tests the robustness of our findings to alternative measures of firm size. First, in column (1) we consider total firm size by including both permanent and temporary workers. Although the Doing Business difficulty of firing index we explore likely captures better the cost of permanent workers, in most countries of our sample firms can choose

\footnotetext{
${ }^{20}$ The sign of the bias is also unclear. On the one hand, one could expect that more enforcement is correlated with larger firm size if there is more enforcement in countries with better institutional quality which in turn is associated with larger firms. On the other hand, more enforcement could be associated with more evasion and smaller firm size if there is more enforcement in places with more evasion and more crime.

${ }^{21}$ The variable requires enough variation within each country, city-sector-size cell. Statistics show that there is enough variation. The standard deviation of the mean inspections is 3.7 days (which compares with 5.2 in the days of labor inspections at the firm level).
} 
whether to offer permanent or temporary contracts. For example, table 1 in the appendix shows that $32 \%$ of the firms in our sample report employing some temporary workers. These account on average for $29 \%$ of the total permanent workforce. A priori it is unclear whether the negative correlation would remain. When firing costs increase it is possible that firms substitute away from permanent to temporary workers so that total firm size may eventually increase. However, it is also possible that the reduction in the permanent employees may not be fully offset by the increase in temporary contracts. The results in column (1) of table A3 show that the magnitude of the effects is still negative but is larger in absolute value than when using only permanent workers. ${ }^{22}$ This implies that when the rigidity of the de facto firing regulations increase the total firm size (captured by permanent and temporary workers) is reduced further. This suggests that firms substitute away labor for other inputs, possibly capital. In column (2) we compute an alternative proxy of firm size. So far we have used the information on firm size in the year prior to the survey. However, the survey also collects data on the numbers of hires and fires during the previous year. With this information we can predict a proxy for current firm size. Finally, in column (3), we proxy total firm size with the logarithm of sales per employee at the firm level. ${ }^{23}$ Across specifications we still find a robust negative correlation between the de facto firing

\footnotetext{
${ }^{22}$ To analyze this issue we have regressed total firm size, measured by the total of permanent employees, in the sample of firms available in column (1) in table A3. This sample is smaller as it excludes firms with missing information for temporary contracts. Our main coefficient of interest is -.00052 and thus is smaller than the one reported in column (1) of table A3. In addition, we also run our baseline specification using the number of temporary workers as the dependent variable. We find a negative and statistically strong coefficient.

${ }^{23}$ Other studies in the literature also look at the effects of labor regulations on firm’s sales (e.g. Micco and Pagés, 2006; Almeida and Carneiro, 2007, 2009).
} 
regulations and firm size. The only exception is for sales per employee whose effect is still negative but not statistically strong. ${ }^{24}$

Finally, we have also estimated equation (1) also using share of skilled workers as our dependent variable. We found robust evidence that stricter de facto firing regulations are associated with a more skilled workforce. This is in line with the results found by others that stringent regulations disproportionally hurt the unskilled workers (available on request).

\subsection{Heterogeneity of the Effects}

This section discusses several robustness checks for different samples. The first issue we discuss is whether the results are different for firms using different technologies. One might argue that firms differ in their need to adjust labor depending on the degree of the technological sophistication. Column (1) of table 4 restricts the sample only to manufacturing firms. In columns (2) and (3) we run the regression separately for high-tech and low-tech manufacturing firms. ${ }^{25}$ Results shows that an increase in the stringency of the de facto firing regulations reduces firm size more in manufacturing firms than in services. In addition, the results in columns (2) and (3) show more pronounced effects for the low-tech manufacturing firms, which are relatively more dependent on labor. This follows the findings in Micco and Pagés (2006) who also find that low-tech firms are more affected by labor regulations.

Another possible concern is that our findings are driven by a possible sorting of firms into countries and regions with looser or stricter degrees of de facto firing regulations. For

\footnotetext{
24 Our results in columns (1) and (2) of table A3 go through all the specifications in table 2. Results are not presented but available upon request.

${ }^{25}$ We follow Parisi et al. (2006) and define low-tech industries as follows: Beverages, food, garments, leather, nonmetallic and plastic materials, other manufacturing, textiles and wood and furniture.
} 
example, recent empirical work has shown the importance of labor market conditions in the receiving country in attracting foreign firms. ${ }^{26}$ In column (4), we therefore restrict our sample only to domestic firms. This is likely a group of firms that is less sensitive to changing its location depending on the institutional quality and on the enforcement of regulations and laws. Again, our main results remain showing that firms facing a stricter enforcement of firing costs tend to have smaller firm size.

Finally, in many countries regulations simply do not apply to firms below a given threshold. In the absence of data on enforcement, some studies have explored this discontinuity in the application of the de jure law to identify the effects of labor regulations on different labor market outcomes (Boeri and Jimeno, 2005; Schivardi and Torrini, 2008; Abidoye et al., 2009). In our data it is also true that there is greater enforcement levels for firms of larger sizes (see Figure 1). To check whether our findings are affected by this variation in the enforcement, column (5) reports the results of our baseline specification for the set of firms only with more than 5 workers. ${ }^{27}$ It is reassuring to see that our results remain robust when we exclude from the sample this group of firms, possibly facing weaker enforcement.

Table 5 presents additional robustness checks. First, stricter firing costs may have differential impacts on firm size depending on the age of the firm. In particular, it is plausible that older firms, having done their decision on the technology and size of the workforce while back, will react less to increases in the current de facto stringency of firing regulations. In

\footnotetext{
${ }^{26}$ For example, Haaland and Wooton (2003) and Javorcik and Spatareanu (2008) document a positive correlation between labor market flexibility and foreign direct investment. Amiti and Javorcik (2008) find that lower labor costs in the country of destination are also associated with attracting foreign firms.

${ }^{27}$ In addition, we test the robustness of our findings when excluding firms with fewer than 10 or 20 employees. The results are not reported but are available on request.
} 
contrast, younger firms which have made their decisions more recently may respond more. Columns (1) and (2) in Table 5 test this hypothesis. As expected, younger firms seem to be relatively more affected more stringent de facto firing regulations. Second, we test whether our results are driven by the low income economies. ${ }^{28}$ Third, in columns (4) to (7) we test whether our findings are being driven by a specific region of the world by removing the countries in East Asia and Pacific, Europe and Central Asia, Latin America and Caribbean and North Africa and Middle East, respectively, from the sample. Reassuringly, our main findings remain and imply significant changes in the size of the firms throughout all columns.

Finally, we investigate whether the results hold for countries with stronger or looser rule of law. Columns (8) and (9) of table 5, we divide the sample depending on the values of the rule of law index. The results show that increases in the de facto firing regulations affect firm size especially in countries with better rule of law. The coefficient is still negative, although insignificant, for weak rule of law countries. ${ }^{29}$ This finding confirms the idea that regulations are more binding in countries with better institutional quality, in part because the quality of enforcement is better.

Finally, the last set of robustness checks discusses the sensitivity of the results to alternative models and specifications. Table A4 in the annex check the robustness to considering different non-linear models. First, we consider that the effect of de jure regulation includes a quadratic term. Second, we explore a specification with the logarithm in the firing regulations. Third, we check whether the results are driven only by the countries with high de facto firing

\footnotetext{
${ }^{28}$ We defined countries as low and medium income as per the World Bank's classification in the year the data was collected.

${ }^{29}$ It is reassuring to see that the results for the good rule of law countries go through all of the robustness checks reported in table 2 and in columns (1) through (4) of table 3. (Results are not reported but are available on request).
} 
regulations. The latter implies that countries have de jure firing regulations that are above the average for the sample. Reassuringly, our main findings are stronger for firms facing high levels of de jure firing regulations. This suggests that even when level of firing regulations is high, if these are not enforced, it is unlikely that they will significantly affect firm size. Lastly, in table A5 in the annex, we exclude the outliers in the variable firm size and in the countries with extreme values for the de jure firing regulations. ${ }^{30}$ Again, it is reassuring that our main correlation of interest remains negative and quantitatively important.

\section{Conclusion}

This paper examines the impact of firing regulations on employment and the composition of employment at the firm level in developing countries. We explore the within-country variation in the enforcement of regulations in countries with different stringencies of labor law using a rich firm-level dataset. We find suggestive evidence that stricter firing rules in countries where de jure regulations are more rigid is associated with significantly smaller firm size controlling for firm characteristics and country-sector fixed effects. These effects are stronger in manufacturing and labor intensive firms.

Our results have important policy implications. First, strict firing regulations do constrain firm size in developing countries, as measured by the total number of permanent workers in the firm. Constraints to firm size can have negative consequences for growth if we consider that most of economic growth is due to growth in the existing firms as opposed to growth in the

\footnotetext{
30 In columns (1) and (2) we exclude the countries with the top $1 \%$ and $5 \%$ highest de jure firing regulations, respectively. Cameroon, Cape Verde, Egypt, Estonia, Georgia, Indonesia, Laos and Sri Lanka make the countries with the top 5\% strictest firing regulations. In column (3) we exclude the extreme 5\% values for (log) firm size. The results from excluding the top $1 \%$ and $2 \%$ firms in the (log) size distribution are available upon request.
} 
creation of new firms, as documented in Rajan and Zingales (1998) and Kumar et al. (1999). Second, this impact on firm size may cause lower employment if the numbers of firms in the economy do not rise with stricter firing costs to compensate the fall in firm size.

\section{Bibliography}

Abidoye, Babatunde, Peter Orazem and Milan Vodopivec, "Firing Cost and Firm Size: A Study of Sri Lanka's Severance Pay System," Social Protection Discussion Paper 0916, World Bank, (2009).

Ahsan, Ahmad, and Carmen Pagés, "Are All Regulations Equal? Assessing the Effects of Job Security, Labor Dispute and Contract Labor Laws in India," Journal of Comparative Economics 37, (2009):62-75.

Almeida, Rita, and Pedro Carneiro, "Inequality and Employment in a Dual Economy: Enforcement of Labor Regulation in Brazil" IZA Discussion Paper 3094, (2007).

"Enforcement of Labor Regulation and Firm Size," Journal of Comparative Economics 37 (2009):28-46.

Almeida, Rita, and Reyes Aterido,"On-the-Job Training and Rigidity of Employment Protection in the Developing World: Evidence from Differential Enforcement," Labour Economics, (2011, forthcoming).

Amiti, Mary, and Javorcik Beata S., "Trade costs and location of foreign firms in China," Journal of Development Economics 85, no. 1-2 (2008):129-49.

Aterido, Reyes, and Marie Hallward-Dreimeier and Carmen Pagés, "Investment Climate and Employment Growth: The Impact of Access to Finace, Corruption and Regulations across Firms," IZA Discussion Paper 3138, (2007). 
Besley, Timothy and Robin Burgess, "Can Labor Regulation Hinder Economic Performance? Evidence from India.” The Quarterly Journal of Economics 119 (2004):91-134.

Boeri, Tito, and Juan F. Jimeno, "The Effects of Employment Protection: Learning from Variable Enforcement," European Economic Review 49, (2005): 2057-2077.

Boeri, Tito, Brooke Helppie and Mario Macis, "Labor Regulations in Developing Countries: A Review of Evidence and Directions for Future Research," Social Protection Discussion Paper 0833,World Bank, (2008).

Botero, Juan Carlos, Simeon Djankov, Rafael La Porta, Florencio Lopez de Silanes and Andrei Schleifer, "The Regulation of Labor," NBER Working Paper 0956, (2003).

Caballero, Ricardo, Kevin Cowan, Eduardo Engel, and Alejandro Micco, "Effective Labor Regulation and Microeconomic Flexibilty," NBER Working Paper 10744, (2004).

Haaland, Jan I., and Ian Wooton, "Domestic Labor Markets and Foreign Direct Investment." Review of International Economics 15, (2007):462-80.

Heckman, James, and Carmen Pagés, "Introduction," in James Heckman and Carmen Pagés (eds.), Law and Employment: Lessons from Latin America and the Caribbean, Chicago: University of Chicago Press, (2004):1-108.

Javorcik, Beata S., and Mariana Spatareanu. "Do Foreign Investors Care about Labor Market Regulations?," Review of World Economics 141, (2008):375-403.

Kaufmann, David, and Aart Kraay and Massimo Mastruzzi, "Governance Matters III: Governance Indicators for 1996-2002," World Bank Policy Research Series 3106, (2003).

Kugler, Adriana and Giovanni Pica. "The Effects of Employment Protection and Product Market Regulations on the Italian Labor Market,"in Julian Messina, Cladio Michelacci, Jarkko Turunen 
and Gylfi Zoega (eds.) Labor Market Adjustments in Europe, Massachusetts: Edward Elgar Publishing, (2006).

Kugler, Adriana, "The Effects of Employment Protection in Europe and the U.S.," Els Opuscles del CREI, February 2007.

Kumar, Krishna, Raghuram Rajan and Ruigi Zingales, "What Determines Firm Size?," NBER Working Paper 7208, (1999).

Lazear, Edward, "Job Security Provisions and Employment, "Quarterly Journal of Economics 105 (1990):699-726

Loayza, Norman, and Ana María Oviedo and Luis Servén, "The Impact of Regulation on Growth and Informality: Cross Country Evidence," in Basudeb Guha-Khasnobis, Ravi Kanbur and Elinor Ostrom (eds.) Linking the Formal Economy: Concepts and Policies, New York: Oxford University Press, (2006).

Micco, Alejandro, and Carmen Pagés, "Employment Protection and Gross Job Flows: A Difference-in-Difference Approach," Inter-American Development Bank Research Department Working Paper 508, (2006).

Nickell, Stephen, and Richard Layard, "Labor Market Institutions and Economic Performance," in Orley Ashenfelter and David Card (eds.) Vol. 3, Handbook of Labor Economics, New York: Elsevier, (1999):2711-2805.

Parisi, Maria, Fabio Schiantarelli and Alessandro Sentenelli, "Productivity, Innovation and R\&D: Micro Evidence for Italy," European Economic Review 50 (2006): 2037-2061.

Pierre, Gaëlle, and Stefano Scarpetta. "Employment Protection: Do Firms' Perceptions Match with Legislation?," Economics Letters 90 (2006):328-34. 
Rajan, Raghuram, and Luigi Zingales, "Financial Dependence and Growth," American Economic Review 88 (1998):559-86.

Ronconi, Lucas, "Enforcement and Compliance with Labor Regulations in Argentina," Industrial and Labor Relations Review 64, 2010:719-36.

Schivardi, Fabiano, and Roberto Torrini, "Identifying the Effects of Firing Restrictions through Size-Contingent Differences in Regulation," Labor Economics 115, (2008):482-511.

Schneider, Friedrich, "Shadow Economies of 145 Countries All Over the World: What Do We Really Know?," CREMA Working Papers 13, (2003).

Svensson, Jakob, "Who Must Pay Bribes And How Much? Evidence From A Cross Section Of Firms," Quarterly Journal of Economics 118 (2003):207-30.

United Nations, Unleashing Enrepreneurship: Making Business Work for the Poor? UNDP Commission Report, New York, United Nations, (2004). 
Figure 1

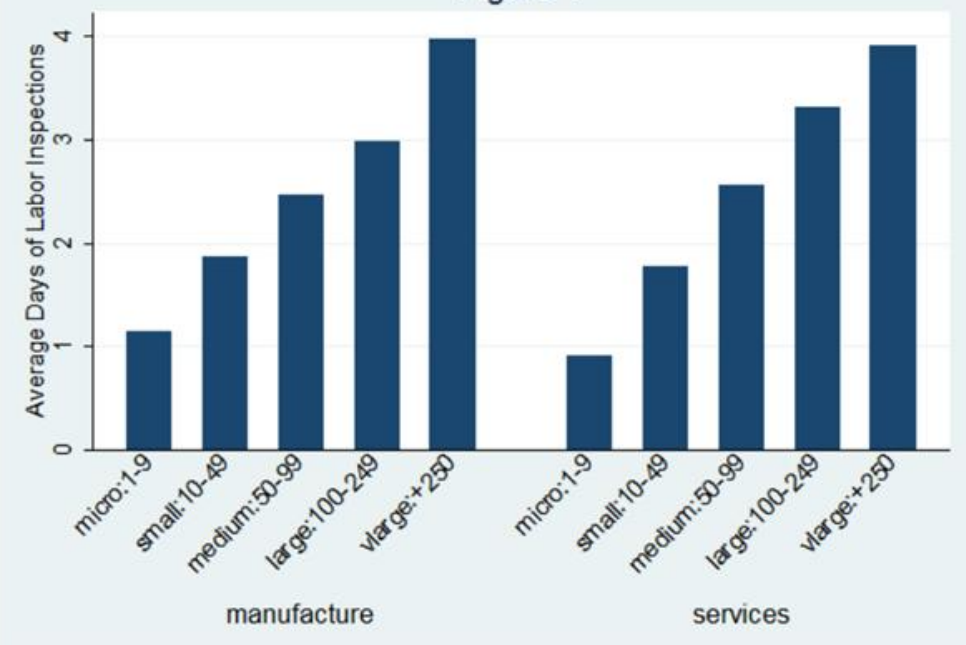


Figure 2

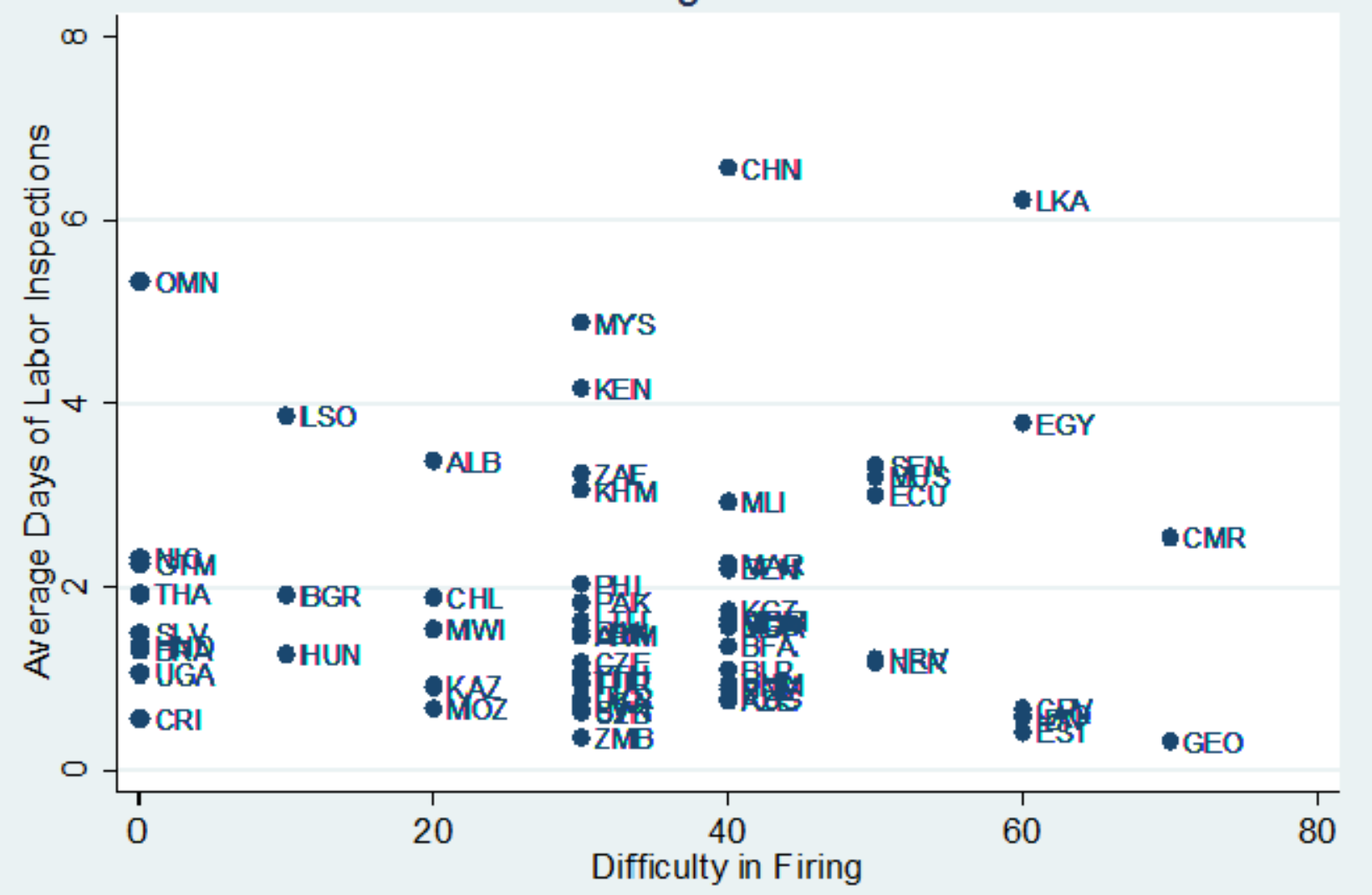


Table 1: Summary Statistics of the Main Variables

\begin{tabular}{|c|c|c|c|c|c|}
\hline Firm Level Variables & $\mathrm{N}$ & Mean & Std. Dev. & Min & Max \\
\hline Permanent workers & 30,351 & 211.70 & 1021.9 & 1 & 67,598 \\
\hline Log Firm Size & 30,351 & 3.83 & 1.65 & 0 & 11 \\
\hline Temporary workers & 9,804 & 98.25 & 1178.87 & 1 & 80,000 \\
\hline Share of temporary workers (\% of total workforce) & 9,804 & 29.01 & 24.61 & 0 & 100 \\
\hline Estimated firm size & 30,287 & 222.51 & 1037.82 & 1 & 67,598 \\
\hline Age & 29,435 & 17.36 & 16.58 & 0 & 215 \\
\hline Capital city (dummy) & 28,854 & 0.29 & 0.45 & 0 & 1 \\
\hline City populated more than 1 million (dummy) & 28,854 & 0.23 & 0.42 & 0 & 1 \\
\hline City populated between 250k and 1 million (dummy) & 28,854 & 0.16 & 0.37 & 0 & 1 \\
\hline City populated between 50k and 250k (dummy) & 28,854 & 0.18 & 0.38 & 0 & 1 \\
\hline City populated less than 50k (dummy) & 28,854 & 0.14 & 0.35 & 0 & 1 \\
\hline Exporter (dummy) & 29,918 & 0.31 & 0.46 & 0 & 1 \\
\hline Minority Foreign Ownership (dummy) & 30,246 & 0.03 & 0.17 & 0 & 1 \\
\hline Majority Foreign Ownership (dummy) & 30,246 & 0.05 & 0.21 & 0 & 1 \\
\hline Full Foreign Ownership (dummy) & 30,246 & 0.06 & 0.24 & 0 & 1 \\
\hline Public Ownership (dummy) & 30,151 & 0.08 & 0.27 & 0 & 1 \\
\hline Days of Labor Inspections in the Firm & 30,351 & 2.33 & 5.25 & 0 & 55 \\
\hline Days of Total Inspections in the Firm & 30,351 & 10.45 & 16.47 & 0 & 265 \\
\hline Sales per Employee & 28,213 & 2747.69 & 82,892 & 0 & $11,500,000$ \\
\hline Mgmt Time Spent Dealing with Officials (\%) & 26,916 & 8.61 & 13.23 & 0 & 100 \\
\hline Manager's Perception on Property Rights Enforced in the Country & 26,430 & 0.59 & 0.49 & 0 & 1 \\
\hline Manager's Perception on Regulations Consistent in the Country & 23,055 & 0.49 & 0.50 & 0 & 1 \\
\hline \multicolumn{6}{|l|}{ Country Level Variables } \\
\hline Difficulty in Firing & 30,351 & 30.11 & 18.08 & 0 & 70 \\
\hline Rigidity of Employment Index & 30,351 & 34.39 & 11.86 & 7 & 70 \\
\hline Rule of Law & 30,351 & -0.27 & 0.53 & -1.31 & 1 \\
\hline Control of Corruption & 30,351 & -0.33 & 0.54 & -1.15 & 1 \\
\hline Regulatory Quality & 30,351 & -0.11 & 0.62 & -1.71 & 1 \\
\hline (Log) GDP per capita (WDI, in 2000 dollars) & 30,351 & 7.28 & 0.94 & 4.85365 & 9 \\
\hline
\end{tabular}

Source: Author's calculations based on the Enterprise Surveys (World Bank) unless otherwise stated in parantheses.

Difficulty in Firing are Rigidity of Employment taken from the Doing Business database.Rule of Law, Control of Corruption and Regulatory Quality are from 31

Kaufmann et al. (2003) 


\begin{tabular}{|c|c|c|c|c|c|c|c|c|}
\hline (1) & (2) & (3) & (4) & (5) & (6) & (7) & (8) & (9) \\
\hline-0.00086 & -0.00073 & -0.00068 & -0.00062 & -0.00067 & -0.00059 & -0.00062 & -0.00068 & -0.00058 \\
\hline$[0.00019]^{* * *}$ & {$[0.00015]^{* * *}$} & {$[0.00015]^{* * *}$} & {$[0.00016]^{* * *}$} & {$[0.00017]^{* * *}$} & {$[0.00015]^{* * *}$} & {$[0.00015]^{* * *}$} & {$[0.00016]^{* * *}$} & {$[0.00016]^{* * *}$} \\
\hline - & - & $\begin{array}{l}-0.00007 \\
{[0.00006]}\end{array}$ & $\begin{array}{l}-0.00007 \\
{[0.00006]}\end{array}$ & $\begin{array}{c}-0.00007 \\
{[0.00006]}\end{array}$ & $\begin{array}{c}-0.00007 \\
{[0.00006]}\end{array}$ & $\begin{array}{l}-0.00007 \\
{[0.00006]}\end{array}$ & $\begin{array}{l}-0.00006 \\
{[0.00006]}\end{array}$ & $\begin{array}{l}-0.00007 \\
{[0.00006]}\end{array}$ \\
\hline 0.06607 & 0.05040 & 0.02879 & 0.00660 & 0.04458 & 0.06889 & 0.05867 & 0.06119 & -0.02133 \\
\hline$[0.00742] * * *$ & {$[0.00586]^{* * *}$} & {$[0.00583]^{* * *}$} & {$[0.03053]$} & {$[0.04367]$} & {$[0.04113]^{*}$} & [0.04205] & {$[0.03344]^{*}$} & {$[0.03406]$} \\
\hline - & - & $\begin{array}{c}0.01252 \\
{[0.00240]^{* * *}}\end{array}$ & $\begin{array}{c}0.01255 \\
{[0.00240]^{* * *}}\end{array}$ & $\begin{array}{c}0.01253 \\
{[0.00240]^{* * *}}\end{array}$ & $\begin{array}{c}0.01244 \\
{[0.00240]^{* * *}}\end{array}$ & $\begin{array}{c}0.01249 \\
{[0.00240]^{* * *}}\end{array}$ & $\begin{array}{c}0.01245 \\
{[0.00239]^{* * *}}\end{array}$ & $\begin{array}{c}0.00585 \\
{[0.00387]}\end{array}$ \\
\hline - & - & - & $\begin{array}{c}0.00280 \\
{[0.00399]}\end{array}$ & $\begin{array}{l}-0.00191 \\
{[0.00538]}\end{array}$ & $\begin{array}{l}-0.00558 \\
{[0.00538]}\end{array}$ & $\begin{array}{l}-0.00378 \\
{[0.00529]}\end{array}$ & $\begin{array}{c}0.00001 \\
{[0.00394]}\end{array}$ & $\begin{array}{c}0.00465 \\
{[0.00410]}\end{array}$ \\
\hline - & - & - & - & $\begin{array}{c}0.00915 \\
{[0.00814]}\end{array}$ & - & - & - & - \\
\hline - & - & - & - & - & $\begin{array}{c}0.01725 \\
{[0.00733]^{* *}}\end{array}$ & - & - & - \\
\hline - & - & - & - & - & - & $\begin{array}{c}0.01342 \\
{[0.00746]^{*}}\end{array}$ & - & - \\
\hline - & - & - & - & - & - & - & $\begin{array}{c}-0.00281 \\
{[0.00101]^{* * *}}\end{array}$ & - \\
\hline - & - & - & - & - & - & - & - & $\begin{array}{c}0.00050 \\
{[0.00029]^{*}}\end{array}$ \\
\hline No & Yes & Yes & Yes & Yes & Yes & Yes & Yes & Yes \\
\hline $\begin{array}{c}30,351 \\
-0.26\end{array}$ & $\begin{array}{c}27,387 \\
-0.26\end{array}$ & $\begin{array}{c}27,387 \\
-0.24\end{array}$ & $\begin{array}{c}27,387 \\
-0.19\end{array}$ & $\begin{array}{c}27,387 \\
-0.24\end{array}$ & $\begin{array}{c}27,387 \\
-0.21\end{array}$ & $\begin{array}{c}27,387 \\
-0.22\end{array}$ & $\begin{array}{c}27,387 \\
-0.24\end{array}$ & $\begin{array}{c}27,387 \\
-0.21\end{array}$ \\
\hline
\end{tabular}

Differential in (log) Firm Size (P90-P10)

0.19

$-0.24$

Dependent variable is the logaritm of permanent employees at the firm level. Table reports the least squares coefficients of eq. (1) in the paper. Robust standard errors clustered at the country-sector level are in brackets. * significant at $10 \%,{ }^{* *}$ significant at $5 \%,{ }^{* * *}$ significant at $1 \%$. Basic firm level controls include age of the firm (and its square), export status, fully, majority and minority foreign-ownership (dummies), public ownership (dummy), and four city dummies. Country-sector fixed effects are included in all regressions. P90-P10 differential is reported in last row. It quantifies the impact on log firm size of increasing enforcement from percentile $10^{\text {th }}$ to percentile $90^{\text {th }}$ in a country with looser firing regulations (at the $10^{\text {th }}$ percentile) relative to the same change in a country with stricter firing regulations (at the $90^{\text {th }}$ percentile). All variables are defined in Table A1. 
Labor Inspections in the Firm * Difficulty in Firing

Total Inspections in the Firm* Difficulty in Firing

Labor Inspections in the Firm

Total Inspections in the Firm

Difficulty in Firing * Management Time Spent Dealing with Officials

Difficulty in Firing * Manager's Perception on Property Rights Enforced in the Country

Difficulty in Firing * Manager's Perception on Regulations Consistent in the Country

GDP pc * Labor Inspections

Basic Firm Level Controls Included?

Observations

Differential in (log) Firm Size (P90-P10)
Av. Labor

Inspections

Smoother

Inspections at the Firm Level

the City-Size-

Enforcement

Sector

Variable

\begin{tabular}{|c|c|c|c|c|}
\hline \multicolumn{5}{|c|}{ Sector } \\
\hline (1) & (2) & (3) & (4) & (5) \\
\hline-0.00045 & -0.00053 & -0.00038 & -0.00150 & -0.00339 \\
\hline$[0.00019]^{* *}$ & {$[0.00015]^{* * *}$} & {$[0.00016]^{* *}$} & {$[0.00040]^{* * *}$} & {$[0.00058]^{* * *}$} \\
\hline-0.00022 & -0.00003 & -0.00015 & 0.00001 & -0.00009 \\
\hline$[0.00008]^{* * *}$ & {$[0.00007]$} & {$[0.00008]^{*}$} & {$[0.00011]$} & {$[0.00006]$} \\
\hline-0.03179 & -0.02630 & -0.11384 & 0.14995 & 0.10827 \\
\hline [0.03547] & [0.02997] & {$[0.03050]^{* * *}$} & {$[0.06298]^{* *}$} & [0.10931] \\
\hline 0.01860 & 0.01327 & 0.01802 & 0.00830 & 0.01279 \\
\hline$[0.00330]^{* * *}$ & {$[0.00252]^{* * *}$} & {$[0.00292]^{* * *}$} & {$[0.00414]^{* *}$} & {$[0.00231]^{* * *}$} \\
\hline-0.00046 & - & - & - & - \\
\hline \multicolumn{5}{|l|}{$[0.00011]^{* * *}$} \\
\hline - & $\begin{array}{c}-0.00301 \\
{[0.00434]}\end{array}$ & - & - & - \\
\hline - & - & $\begin{array}{l}-0.00289 \\
{[0.00393]}\end{array}$ & - & - \\
\hline Yes & Yes & Yes & Yes & Yes \\
\hline Yes & Yes & Yes & Yes & Yes \\
\hline 24,140 & 23,789 & 20,522 & 27,387 & 27,387 \\
\hline-0.11 & -0.16 & -0.09 & -0.54 & -0.41 \\
\hline
\end{tabular}

Source: Author's calculations based on the Enterprise Surveys

Dependent variable is the logaritm of permanent employees at the firm level. Table reports the least squares coefficients of eq. (1) in the paper. Robust standard errors clustered at the countrysector level are in brackets. * significant at $10 \%, * *$ significant at $5 \%, * *$ significant at $1 \%$. Basic firm level controls include age of the firm (and its square), export status, fully, majority and minority foreign-ownership (dummies), public ownership (dummy), and four city dummies. Country-sector fixed effects are included in all regressions. P90-P10 differential is reported in last row. It quantifies the impact on log firm size of increasing enforcement from percentile $10^{\text {th }}$ to percentile $90^{\text {th }}$ in a country with looser firing regulations (at the $10^{\text {th }}$ percentile) relative to the same change in a country with stricter firing regulations (at the $90^{\text {th }}$ percentile). All variables are defined in Table A1. In column (4) enforcement is proxied by average of labor inspections in the city-sector-size where the firm is operating, (excluding the firm's own value). In column (5) enforcement is proxied by a discrete variable taking on four values depending on whether the firm has labor inspections smaller than $25^{\text {th }}$ percentile of the labor inspections in the country, has labor inspections between $25^{\text {th }}$ and $50^{\text {th }}$ percentile of the labor inspections in the country, has labor inspections between $50^{\text {th }}$ and $75^{\text {th }}$ percentile of the labor inspections in the country, has labor inspections more than the $75^{\text {th }}$ percentile of the labor inspections in the country. 
Manufacturing

$\begin{array}{lll}\text { All } \quad \text { High-Tech Low-Tech } \quad \text { Domestic Firms } & \begin{array}{l}\text { Firms with more } \\ \text { than } 5 \text { employees }\end{array}\end{array}$

(1)

$(2)$

(3)

(4)

(5)

Labor Inspections in the Firm * Difficulty in Firing

$\begin{array}{cc}-0.00086 & -0.00060 \\ {[0.00015]^{* * *}} & {[0.00033]^{*}} \\ 0.03509 & -0.10577 \\ {[0.03134]} & {[0.05608]^{*}}\end{array}$

-0.00087
$[0.00018]^{* * *}$

$-0.00057$

0.07154

$[0.00018]^{* * *}$

$0.03308]^{* *}$

0.01789

$-0.00058$

\section{Labor Inspections in the Firm}

Basic Firm Level Controls Included?

\section{Observations}

Differential in (log) Firm Size (P90-P10)

$\begin{array}{cc}\text { Yes } & \text { Yes } \\ 20,766 & 6,825 \\ -0.31 & -0.36\end{array}$

Yes
13,941
-0.26

[0.03565]

$[0.00015]^{* * *}$

0.00603

$0.02609]$

Source: Author's calculations based on the Enterprise Surveys.

Dependent variable is the logaritm of permanent employees at the firm level. Table reports the least squares coefficients of eq. (1) in the paper. Robust standard errors clustered at the countrysector level are in brackets. * significant at $10 \%,{ }^{* *}$ significant at $5 \%, * * *$ significant at $1 \%$. Basic firm level controls include age of the firm (and its square), export status, fully, majority and minority foreign-ownership (dummies), public ownership (dummy), and four city dummies. Country-sector fixed effects are included in all regressions. P90-P10 differential is reported in last row. It quantifies the impact on $\log$ firm size of increasing enforcement from percentile $10^{\text {th }}$ to percentile $90^{\text {th }}$ in a country with looser firing regulations (at the $10^{\text {th }}$ percentile) relative to the same change in a country with stricter firing regulations (at the $90^{\text {th }}$ percentile). All variables are defined in Table A1. 
Excluding:

\begin{tabular}{|c|c|c|c|c|c|c|c|c|}
\hline & & $\begin{array}{l}\text { Low Income } \\
\text { Countries }\end{array}$ & $\begin{array}{l}\text { East Asia and } \\
\text { Pacific }\end{array}$ & $\begin{array}{c}\text { Europe and } \\
\text { Central Asia }\end{array}$ & $\begin{array}{l}\text { Latin America } \\
\text { and Caribbean }\end{array}$ & $\begin{array}{l}\text { North Africa } \\
\text { \& MENA }\end{array}$ & $\begin{array}{l}\text { Good Rule of } \\
\text { Law Countries }\end{array}$ & $\begin{array}{l}\text { Bad Rule of Law } \\
\text { Countries }\end{array}$ \\
\hline (1) & (2) & (3) & (4) & (5) & (6) & (7) & (8) & (9) \\
\hline $\begin{array}{c}-0.00085 \\
{[0.00048]^{*}}\end{array}$ & $\begin{array}{c}-0.00061 \\
{[0.00017]^{* * *}}\end{array}$ & $\begin{array}{c}-0.00043 \\
{[0.00019]^{* *}}\end{array}$ & $\begin{array}{c}-0.00057 \\
{[0.00022]^{* * *}}\end{array}$ & $\begin{array}{c}-0.00079 \\
{[0.00015]^{* * *}}\end{array}$ & $\begin{array}{c}-0.00062 \\
{[0.00022]^{* * *}}\end{array}$ & $\begin{array}{c}-0.00033 \\
{[0.00016]^{* *}}\end{array}$ & $\begin{array}{c}-0.00090 \\
{[0.00021]^{* * *}}\end{array}$ & $\begin{array}{c}-0.00018 \\
{[0.00021]}\end{array}$ \\
\hline $\begin{array}{c}0.08135 \\
{[0.07207]}\end{array}$ & $\begin{array}{c}0.00306 \\
{[0.03211]}\end{array}$ & $\begin{array}{l}-0.07339 \\
{[0.05036]}\end{array}$ & $\begin{array}{l}-0.00822 \\
{[0.03741]}\end{array}$ & $\begin{array}{c}0.06628 \\
{[0.02869]^{* *}}\end{array}$ & $\begin{array}{c}0.02957 \\
{[0.03305]}\end{array}$ & $\begin{array}{c}-0.11120 \\
{[0.04378]^{* *}}\end{array}$ & $\begin{array}{l}-0.00554 \\
{[0.04068]}\end{array}$ & $\begin{array}{c}0.09445 \\
{[0.03114]^{* * *}}\end{array}$ \\
\hline
\end{tabular}

Labor Inspections in the Firm

Basic Firm Level Controls Included?

Observations

Yes

Yes

Yes

Yes

Yes

24,266

20,685

7,880

3,121
-0.17

$-0.22$

$-0.15$

$-0.13$

18,805
-0.34

Yes

Yes

Yes

Yes

Source: Author's calculations based on the Enterprise Surveys.

Dependent variable is the logaritm of permanent employees at the firm level. Table reports the least squares coefficients of eq. (1) in the paper. Robust standard errors clustered at the country-sector level are in brackets. * significant a $10 \%, * *$ significant at $5 \%, * * *$ significant at $1 \%$. Basic firm level controls include age of the firm (and its square), export status, fully, majority and minority foreign-ownership (dummies), public ownership (dummy), and four city dummies Country-sector fixed effects are included in all regressions. P90-P10 differential is reported in last row. It quantifies the impact on log firm size of increasing enforcement from percentile $10^{\text {th }}$ to percentile $90^{\text {th }}$ in a country with looser firing regulations (at the $10^{\text {th }}$ percentile) relative to the same change in a country with stricter firing regulations (at the $90^{\text {th }}$ percentile). All variables are defined in Table A1. Column (1) estimates the base model for firms that are younger than 5 years old and column (2) estimates the base model for firms that are 5 or more years old. Column (1) to (5) estimate the base model excluding from the sample low income countries in column (3) excluding the firms in East Asia and Pacific in column (4), Europe and Central Asia in column (5), Latin America and Caribbean in column (6), and North Africa and Middle East in column (7). Column (8) and (9) estimates the base model by spliting the sample according to the median value of the rule of law indicator taken from Kaufmann and Kraay (2003). 
Table A1. Variables Definitions

\section{Firm Level Variables}

Definition

\begin{tabular}{ll}
\hline Firm Size & Total number of permanent workers. \\
\hline Age & Year of the survey minus the year when
\end{tabular}

Year of the survey minus the year when the firm started operations.

Foreign-Owned : Full, Majoity, Minority

Dummy variables equal to 1 if the firm's capital is entirely owned by foreigners; less than $99 \%$ and more than $50 \%$ owned by

\section{Exporter} foreigners and less than $50 \%$; and less than $50 \%$ and more than $10 \%$ owned by foreigners, respectively.

Public Ownership

Dummy variable equal to 1 if the firm exports directly or indirectly.

Labor Inspections in the Firm

Total Inspections in the Firm

Sales per worker

Dummy variable equal to 1 if the share of the firm's capital owned by the government or state is positive.

\section{Management Time Spent Dealing with Officials}

Number of visits to the firm by labor inspectors.

Number of visits to the firm by all types of inspections (including taxes, heath, safety and labor).

Manager's Perception on Regulations Consistent in the Total sales of the firm divided by the number of its permanent workers, in 2005 dollars.

Country

Percentage of the management's time dealing with government officials.

Manager's Perception on Property Rights Enforced in the Country government in delivering services (e.g. public utilities, public transportation, security, education and health etc.)" is "Somewh efficient", "Efficient" or "Very efficient".

Dummy variable equal to 1 if the response of the firm manager to the question "I am confident that the judicial system will enforce my contractual and property rights in business disputes." To what degree do you agree with this statement?" is "Tend to agree", "Agree in most cases" or "Fully agree".

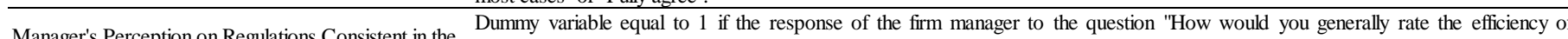

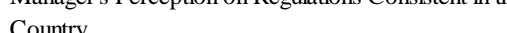
Country Dovernment in delivering services (e public utilities, public transportation, security, education and health etc.)" is "Somewhe efficient", "Efficient" or "Very efficient".

Country Level Variables Definition

Definition Difficulty of Firing Index (Doing Business) : The difficulty of firing index has 8 components: (i) whether redundancy is disallowed as a
basis for terminating workers; (ii) whether the employer needs to notify a third party (such as a government agency) to terminate 1 redundant worker; (iii) whether the employer needs to notify a third party to terminate a group of 9 redundant workers; (iv) whether the employer needs approval from a third party to terminate 1 redundant worker; (v) whether the employer needs approval from a third party to terminate a group of 9 redundant workers; (vi) whether the law requires the employer to reassign or retrain a worker before making the worker redundant; (vii) whether priority rules apply for redundancies; and (viii) whether priority rules apply for reemployment.

Difficulty in Firing

Rigidity of Employment Index (Doing Business) : The rigidity of employment index is the average of 3 subindices: a difficulty of hiring Rigidity of Employment Index (Doing Business) : The rigidity of employment index is the average of 3 subindices. a difficulty of hiring 0 and 100 , with higher values indicating more rigid regulation.

Rigidity of Employment Number of Procedures to start a business (Doing Business): the number of all procedures that are officially required for an entrepreneur to start up and formally operate an industrial or commercial business.

Procedures to Start a Business Government Regulatory Quality (Kaufmann \& Kraay): Regulatory Quality is the ability of the government to formulate and implement sound policies and regulations that permit and promote private sector development.

Regulatory Quality

Government Rule of Law (Kaufmann \& Kraay): the extent to which agents have confidence in and abide by the rules of the society, and in particular the quality of contract enforcement, the police, and the courts as well as the likelihood of crime and violence.

Rule of Law

Government Control Corruption (Kaufmann \& Kraay): Control of Corruption is the extent to which public power is exercised for

Gov. Control Corruption private gain. Including both petty and grand forms of corruption, as well as "capture' of the state by elites and private interests.

GDP per capita

GDP per capita in 2000 dollars (World Development Indicators)

Source: Author's calculations based on the Enterprise Surveys unless otherwise noted in parantheses. 
Table A2. Country/Year Composition of the Sample

\begin{tabular}{|c|c|c|c|c|c|}
\hline & \multicolumn{2}{|c|}{ Freq. } & & Obs & Freq. \\
\hline \multicolumn{3}{|c|}{ SUB-SAHARAN AFRICA } & \multicolumn{3}{|c|}{ EUROPE \& CENTRAL ASIA } \\
\hline Benin2004 & 194 & 0.01 & Albania2005 & 201 & 0.01 \\
\hline BurkinaFaso2006 & 50 & 0.00 & Armenia2005 & 333 & 0.01 \\
\hline Cameroon2006 & 118 & 0.00 & Azerbaijan2005 & 187 & 0.01 \\
\hline CapeVerde2006 & 47 & 0.00 & Belarus 2005 & 308 & 0.01 \\
\hline Ethiopia2002 & 367 & 0.01 & BiH2005 & 173 & 0.01 \\
\hline Kenya2003 & 242 & 0.01 & Bulgaria2005 & 278 & 0.01 \\
\hline Lesotho2003 & 52 & 0.00 & Croatia2005 & 166 & 0.01 \\
\hline Madagascar2005 & 206 & 0.01 & Czech Rep.2005 & 261 & 0.01 \\
\hline Malawi2005 & 155 & 0.01 & Estonia2005 & 139 & 0.00 \\
\hline Mali2003 & 132 & 0.00 & Georgia2005 & 188 & 0.01 \\
\hline Mauritius 2005 & 174 & 0.01 & Hungary2005 & 515 & 0.02 \\
\hline Mozambique2002 & 107 & 0.00 & Kazakhstan2005 & 544 & 0.02 \\
\hline Niger2006 & 125 & 0.00 & Kyrgyzstan2005 & 200 & 0.01 \\
\hline Senegal2003 & 227 & 0.01 & Latvia2005 & 179 & 0.01 \\
\hline SouthAfrica2003 & 578 & 0.02 & Lithuania2005 & 185 & 0.01 \\
\hline Uganda2003 & 297 & 0.01 & Moldova2005 & 338 & 0.01 \\
\hline Zambia2002 & 194 & 0.01 & Poland2005 & 719 & 0.02 \\
\hline \multirow[t]{2}{*}{ Total } & 3,265 & & Romania2005 & 559 & 0.02 \\
\hline & & & Russia2005 & 534 & 0.02 \\
\hline \multirow{2}{*}{\multicolumn{2}{|c|}{ EAST ASIA \& PACIFIC }} & & Slovakia2005 & 156 & 0.01 \\
\hline & & & Turkey2005 & 1641 & 0.05 \\
\hline Cambodia2003 & 184 & 0.01 & Ukraine2005 & 553 & 0.02 \\
\hline China2003 & 3356 & 0.11 & Uzbekistan2005 & 240 & 0.01 \\
\hline Indonesia2003 & 711 & 0.02 & Total & 8,597 & \\
\hline Laos 2005 & 244 & 0.01 & & & \\
\hline Malaysia2002 & 708 & 0.02 & \multicolumn{3}{|c|}{ LATIN AMERICA \& CARIBBEAN } \\
\hline Philippines 2003 & 608 & 0.02 & Brazil2003 & 1634 & 0.05 \\
\hline Thailand2004 & 1384 & 0.05 & Chile2004 & 933 & 0.03 \\
\hline Vietnam2005 & 1471 & 0.05 & CostaRica2005 & 343 & 0.01 \\
\hline \multirow[t]{2}{*}{ Total } & 8,666 & & Ecuador2003 & 434 & 0.01 \\
\hline & & & ElSalvador2003 & 465 & 0.02 \\
\hline \multicolumn{3}{|c|}{ MIDDLE EAST \& NORTH AFRICA } & Guatemala2003 & 435 & 0.01 \\
\hline & & & Honduras 2003 & 449 & 0.01 \\
\hline Egypt2006 & 989 & 0.03 & Nicaragua2003 & 452 & 0.01 \\
\hline Lebanon2006 & 292 & 0.01 & & & \\
\hline Morocco2004 & 827 & 0.03 & Total & 5,145 & \\
\hline Oman2003 & 268 & 0.01 & & & \\
\hline \multirow[t]{6}{*}{ Total } & 2,376 & & SOUTH ASIA & & \\
\hline & & & Bangladesh2002 & 949 & 0.03 \\
\hline & & & Pakistan2002 & 939 & 0.03 \\
\hline & & & SriLanka2004 & 414 & 0.01 \\
\hline & & & Total & 2302 & \\
\hline & & & TOTAL & 30,351 & \\
\hline
\end{tabular}

Source: Author's calculations based on the Enterprise Surveys. 
Table A3: Firing Regulations and Firm Size: Robustness to Alternative Proxies of Firm Size

\begin{tabular}{|c|c|c|c|}
\hline Dependent Variable & Permanent and Temporary Workers & Estimated Firm Size & Sales per Employee \\
\hline & $(1)$ & $(2)$ & (3) \\
\hline Labor Inspections in the Firm* Difficulty in Firing & $\begin{array}{c}-0.00062 \\
{[0.00022]^{* * *}}\end{array}$ & $\begin{array}{c}-0.00061 \\
{[0.00016]^{* * *}}\end{array}$ & $\begin{array}{l}-0.00022 \\
{[0.00025]}\end{array}$ \\
\hline Labor Inspections in the Firm & $\begin{array}{l}-0.04493 \\
{[0.04401]}\end{array}$ & $\begin{array}{c}0.00769 \\
{[0.03116]}\end{array}$ & $\begin{array}{c}0.07211 \\
{[0.02464]^{* * *}}\end{array}$ \\
\hline Basic Firm Level Controls Included? & Yes & Yes & Yes \\
\hline $\begin{array}{l}\text { Observations } \\
\text { Differential in (log) Dependent Variable (P90-P10) }\end{array}$ & $\begin{array}{l}18,666 \\
-0.22\end{array}$ & $\begin{array}{c}27,329 \\
-0.22\end{array}$ & $\begin{array}{c}23,210 \\
-0.08\end{array}$ \\
\hline
\end{tabular}

Source: Author's calculations based on the Enterprise Surveys.

Dependent variable is the logaritm of different measures of firm size that are stated on columns. Table reports the least squares coefficients of eq. (1) in the paper. Robust standard errors clustered at the country-sector level are in brackets. * significant at $10 \%,{ }^{* *}$ significant at $5 \%, * * *$ significant at $1 \%$. Basic firm level controls include age of the firm (and its square), export status, fully, majority and minority foreign-ownership (dummies), public ownership (dummy), and four city dummies. Country-sector fixed effects are included in all regressions. P90-P10 differential is reported in last row. It quantifies the impact on log firm size of increasing enforcement frompercentile $10^{\text {th }}$ to percentile $90^{\text {th }}$ in a country with looser firing regulations (at the $10^{\text {th }}$ percentile) relative to the same change in a country with stricter firing regulations (at the $90^{\text {th }}$ percentile). All variables are defined in Table A1. 


\begin{tabular}{|c|c|c|c|c|}
\hline & Quadratic Regressions & $\begin{array}{c}\text { Log of } \\
\text { Regulations }\end{array}$ & $\begin{array}{c}\text { Countries with } \\
\text { High Firing } \\
\text { Regulations }\end{array}$ & $\begin{array}{c}\text { Countries with } \\
\text { Low Firing } \\
\text { Regulations }\end{array}$ \\
\hline & $(1)$ & $(2)$ & (3) & $(4)$ \\
\hline Labor Inspections in the Firm* Difficulty in Firing & $\begin{array}{l}-0.00035 \\
{[0.00044]}\end{array}$ & $\begin{array}{c}-0.02558 \\
{[0.00870]^{* * *}}\end{array}$ & $\begin{array}{c}-0.00098 \\
{[0.00045]^{* *}}\end{array}$ & $\begin{array}{c}-0.00076 \\
{[0.00031]^{* *}}\end{array}$ \\
\hline Labor Inspections in the Firm* (Difficulty in Firing) ${ }^{2}$ & $\begin{array}{c}0.00000 \\
{[0.00001]}\end{array}$ & - & - & - \\
\hline Basic Firm Level Controls Included? & Yes & Yes & Yes & Yes \\
\hline Observations & 27,387 & 22,148 & 12,025 & 15,362 \\
\hline Differential in (log) Firm Size (P90-P10) & -0.23 & -0.17 & -0.20 & -0.06 \\
\hline F-Test: Ho: $E^{*} \mathrm{R}=\mathrm{E}^{*} \mathrm{R}^{2}=0$ & 7.71 & & & \\
\hline
\end{tabular}

Source: Author's calculations based on the Enterprise Surveys.

Dependent variable is the logaritm of permanent employees at the firm level. Table reports the least squares coefficients of eq. (1) in the paper. Robust standard errors clustered at the country-sector level are in brackets. * significant at 10\%, ** significant at 5\%, *** significant at $1 \%$. Basic firm level controls include age of the firm (and its square), export status, fully, majority and minority foreign-ownership (dummies), public ownership (dummy), and four city dummies. Country-sector fixed effects are included in all regressions. P90-P10 differential is reported in last row. It quantifies the impact on log firm size of increasing enforcement from percentile $10^{\text {th }}$ to percentile $90^{\text {th }}$ in a country with looser firing regulations (at the $10^{\text {th }}$ percentile) relative to the same change in a country with stricter firing regulations (at the $90^{\text {th }}$ percentile). All variables are defined in Table A1. In columns (4) and (5) the sample is divided with respect to the mean value of the difficulty of firing index. (The mean is taken over country values instead of firm values.) 
Labor Inspections in the Firm* Difficulty in Firing

\begin{tabular}{ccc}
\hline $\begin{array}{c}\text { Excluding the top 99\% } \\
\text { regulated countries }\end{array}$ & $\begin{array}{c}\text { Excluding the top 95\% } \\
\text { regulated countries }\end{array}$ & $\begin{array}{c}\text { Excluding the largest and } \\
\text { smallest 5\% firms }\end{array}$ \\
\hline-0.00064 & -0.00052 & -0.00059 \\
{$[0.00016]^{* * *}$} & {$[0.00019]^{* * *}$} & $0.00014]^{* * *}$ \\
0.00768 & -0.00244 & 0.02049 \\
{$[0.03052]$} & {$[0.03167]$} & {$[0.02569]$} \\
-0.00007 & -0.00009 & -0.00004 \\
{$[0.00007]$} & {$[0.00008]$} & {$[0.00005]$} \\
0.01251 & 0.01305 & 0.00909 \\
{$[0.00245]^{* * *}$} & {$[0.00266]^{* * *}$} & {$[0.00194]^{* * *}$} \\
Yes & & Yes \\
27,081 & 25,496 & 21,918 \\
-0.23 & -0.10 & -0.15
\end{tabular}

Differential in (log) Firm Size (P90-P10)

Source: Author's calculations based on the Enterprise Surveys.

Dependent variable is the logaritm of permanent employees at the firm level. Table reports the least squares coefficients of eq. (1) in the paper. Robust standard errors clustered at the country-sector level are in brackets. * significant at 10\%, ** significant at $5 \%, * * *$ significant at $1 \%$. Basic firm level controls include age of the firm (and its square), export status, fully, majority and minority foreign-ownership (dummies), public ownership (dummy), and four city dummies. Country-sector fixed effects are included in all regressions. P90-P10 differential is reported in last row. It quantifies the impact on log firm size of increasing enforcement from percentile $10^{\text {th }}$ to percentile $90^{\text {th }}$ in a country with looser firing regulations (at the $10^{\text {th }}$ percentile) relative to the same change in a country with stricter firing regulations (at the $90^{\text {th }}$ percentile). All variables are defined in Table A1. Column (1) excludes firms in Cameroon and Georgia. Column (2) excludes firms in Cameroon, Capeverde, Egypt, Estonia, Georgia, Indonesia, Laos and Sri Lanka. 